\title{
Lluvia Enojada-Tyoo Kuasi': The Political Ecology of Forest Extraction in the Sierra Chatina, Oaxaca, Mexico ${ }^{1}$
}

\author{
Robert M. Emanuel and James B. Greenberg
}

The Sierra Chatina (see Figure 1) is inhabited by some of the poorest indigenous communities in Mexico, yet possesses pine and oak forests that are among the most valuable timberlands in Mexico (A. González R. and N. Rodríguez 1995:85; S. Nahmad et al. 1993). Over the last 25 years, rural development has led to large-scale environmental changes in the Sierra Chatina. The most visible has been the loss of 40 percent of the area's natural vegetation (D. Liverman and M. Patterson n.d.). Deforestation has not only accelerated climatic changes in the region, but has exacerbated the devastating effects of flooding as Hurricanes Pauline and Rick proved only too tragically in the fall of 1997.

This paper briefly outlines the major activities contributing to deforestation and examines the role played by neoliberal restructuring in these processes. Although commercial logging has been the primary factor in deforestation in the Sierra Chatina, a host of secondary processes have contributed to deforestation as well. These include a mix of local subsistence activities, agropastoral activities, coffee production, and fuel wood harvest. Although the Chatino have long managed their forests successfully, timber companies-backed by Federal forestry policies - have wrested control over forests from local communities. ${ }^{2}$ These companies have overexploited these forests, and the Chatino have become victims of the ecosystem's degradation.

In this paper, we argue that the Mexican government's neoliberal policies have encouraged the commoditization of the Sierra Chatina forests at the expense of long-term ecological

1. This paper is based on both continuous research conducted since the early 1970s by Greenberg and on research conducted during the summer of 1998 by Robert Emanuel. Fieldwork conducted by the latter has been funded in part by the Tinker Foundation administered through the Latin American Area Center at the University of Arizona. The authors are grateful for the institutional support of the Centro de Investigaciones y Estudios en Antropología Social, Centro Suroeste, Oaxaca. Robert Emanuel also gratefully acknowledges Gina Campbell Emanuel and members of the Zavaleta family for invaluable assistance in research and support.

2. There is a growing consensus worldwide that local participation in forest management is one of the few viable ways to achieve their sustainable use (D. Goodman and M. Redclift 1991). Without the participation of local communities the risks of overexploiting such forests are overwhelming (A. González R. and N. Rodríguez 1995; C. Zabin 1998). 
sustainability. Since 1992, Mexico has moved toward privatization of forests by removing the legal roadblocks to leasing of ejido and communal lands. Moreover, as neoliberal policies have devalued the currency and eliminated subsidies, the Chatino have been pushed deeper into poverty, and into unsustainable uses of their forests. Thus, we contend that transformations of land-use patterns seen in these coastal mountains are part of a fundamental shift in local livelihoods from subsistence to cash-based strategies. The impacts of these social processes became readily apparent when coupled with the El Niño-driven climatic events of 1997 and 1998.

FIGURE 1. Map of the district of Juquila, Oaxaca, México, and the principal towns of the Sierra Chatina. (Source: J. Greenberg 1981)

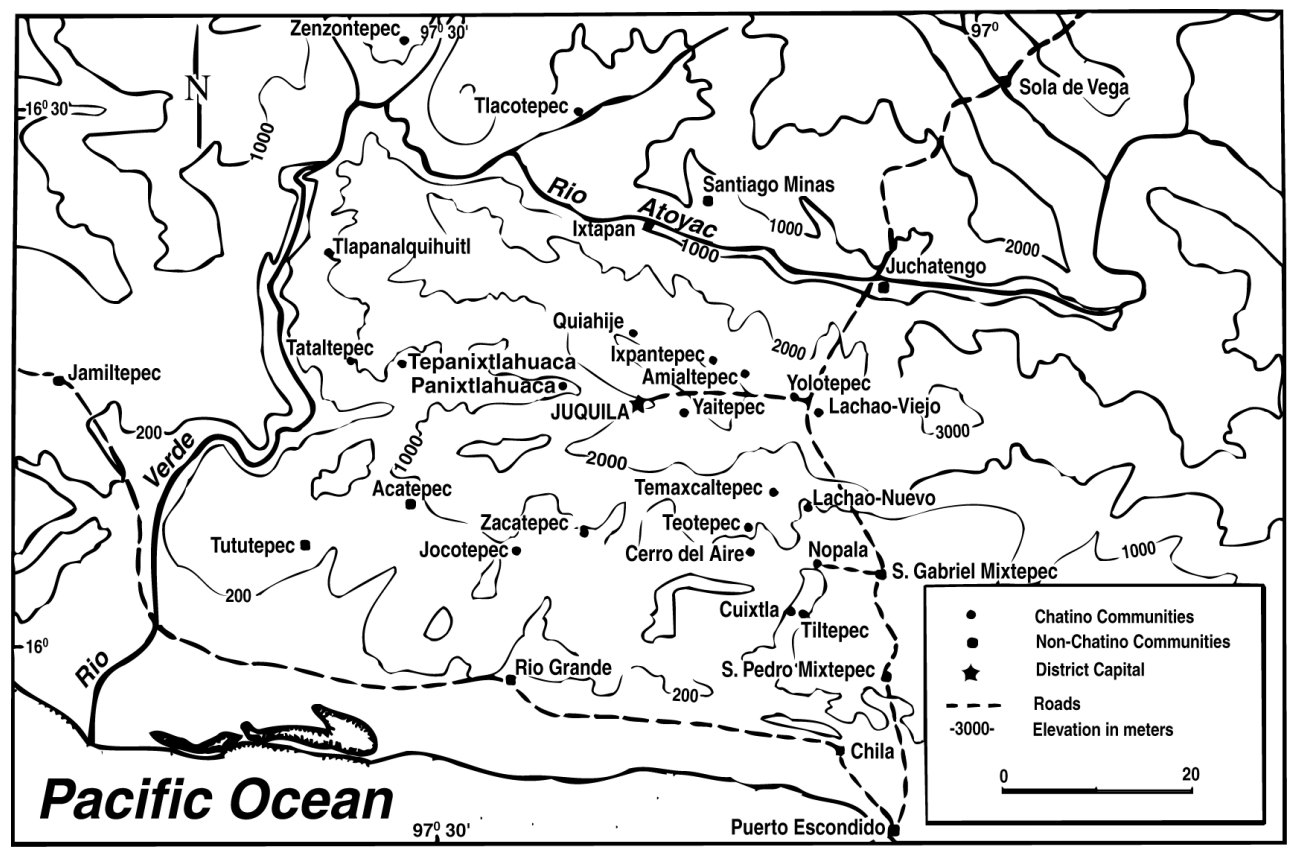

\section{Changing Forest Policies and the State}

Over the past three decades, a number of changes in the Mexican government's forest policies have made it increasingly easy for commercial firms to obtain logging rights on communal and ejido lands. In the 1970s and early 1980s, Mexican forestry was a textbook example of state-sponsored modernization based on import substitution industrialization (ISI) (C. Zabin 1993). Direct government investment took the form of large parastatal pulp and paper mills, sawmills, and factories. The federal government not only granted large parastatal and private firms concessions to exploit communal or ejidal forests, but also protected these firms from foreign competition by limiting timber imports. Further, to facilitate commercial exploitation of forests, the nation-state bore the costs of building new roads and infrastructure (C. Zabin 1998). Since the 1930s, permission to harvest 
timber on ejido and communal lands involved obtaining permits from Byzantine federal and state bureaucracies. In theory, the responsible local officials, comisariados de bienes comunales (communal lands commissioners) were supposed to come from the community and were mandated to follow national agrarian laws; but, in practice, because few Chatino were bilingual, and still fewer literate, mestizos from Juquila or other Ladino towns were regularly hired as their municipal secretaries and/or bienes comunales. These officials often engineered the leasing timber rights to communal lands. Occasionally, they even cut deals that the Chatino communities became aware of only when the company showed up to cut a tract of timber.

During the early 1970s, when Greenberg first worked in the region, commercial logging in the Sierra Chatina was still in its initial phases. The rough gravel or dirt roads into the region were barely a decade old. What roads did exist were very primitive, washed out regularly, and reached only a few communities. During this period, forestry policy was typified by a thick layering of bureaucracies that linked powerful local elites with more powerful elites in urban centers such as Oaxaca, and Mexico City. Fields of power emanated from these city centers out through the apparatus of patronage and privilege embedded in the Partido Revolucionario Institucional (PRI) and local political bossescaciques - often based in economic and political centers such as Juquila, who in turn, manipulated the comisariado de bienes comunales in their satellite communities.

Although legal commercial sales were rare during the 1970s and early 1980s, some did occur-even in the most remote areas. In the Sierra Chatina the huge parastatal Fabricas de Papel Tuxtepec (FAPATUX), and the private firm Compañía de Bosques de Oaxaca (CIBO) were active. Complimenting its already massive 251,825 ha. of timber holdings in the Sierra Juarez of northern Oaxaca (D. Bray and M. Wexler 1996:218), FAPATUX gained large concessions in the Chatino municipios of Santa Cruz Zenzontepec and Panixtlahuaca. However, the company's wholesale pillaging of forests led to its violent expulsion from at least one municipio in the early 1980s (Nahmad et al. 1994:110). Where FAPATUX extracted large quantities of timber, forests were extremely degraded. The direct outcome of FAPATUX's forest management practices of "rejuvenation" and "thinning" were monocultures of young, economically viable species such as pine at the expense multi-storied forests containing a variety of trees such as oaks and other deciduous species. Where "thinning" was practiced, the company "high graded" or harvested the best trees, leaving diseased or genetically inferior specimens to reseed the forest (D. Bray and M. Wexler 1996:220). The result was the rapid loss of watershed integrity and biodiversity. The brief history of CIBO in the Sierra Chatina from 1983 to 1988, although not as detrimental to the forests of the area, saw the extraction of over $5,000 \mathrm{~m} 3$ of wood. However, the local communities that had sold their timber to CIBO received only one-tenth of its actual market price (S. Nahmad et al. 1994:111f).

Overall, the political economy of the Sierra Chatina did not allow the small producer, whether mestizo or indigenous, to succeed in cutting and marketing their forests because the highest profits could only be garnered from finished and manufactured wood products such as finished saw-timber, paper, and particleboard. Because Sierra peasants could not produce more than unfinished logs and lacked the transportation and finishing infrastructure to produce a valuable product, peasants and poor, indigenous communities were not able to compete effectively with the highly capitalized, mestizo-dominated companies from Oaxaca or other urban centers in Mexico (S. Nahmad et al. 1993). Nor have many indigenous or poor mestizo peasants had the social capital—education and 
literacy-necessary to hire the technical staff or wade through the miles of state-mandated paperwork that, at least in theory, regulated timber harvesting until recently (C. Zabin 1998).

Prior to their commercialization, forests and forest products in the Sierra Chatina were merely locally valued resources, and not commodities in world markets. Because timber and other forest-products were valued at local market prices, the resources were uninteresting to most peasants. Instead, forests were viewed as a resource for fuel wood, for local building materials, for medicinal and edible plants, a haven for game, and a cosmologically significant center of ancestral or spiritual power in Chatino moral ecology (J. Greenberg 1981; A. González R. 1995). With profound changes in public policy and their commercialization, all of this has changed dramatically.

In 1986, a new federal forestry law was enacted that ended the direct state sponsorship of concessions in the communities, making it more difficult for large firms to extort longterm contracts for timber harvest from poorly organized communities. This legislation also favored smaller, more competitive firms, over large parastatal enterprises. Most importantly, the new legislation granted local communities control of logging contracts, returning to them control of their forest resources (C. Zabin 1998). Under this law communities were entitled to hire their own technical service providers-called Forestry Conservation and Development Units (UCODEFOs). The services of UCODEFOs included forest management plans, reforestation programs, and auditing cuts and market values. Few communities in the Sierra Chatina however were sufficiently organized to hire UCODEFOs to take advantage of their technical assistance. Despite the high hopes of community forestry advocates, the 1986 Forestry Law and the agency responsible for its enforcement, the Forest Sub secretariat, suffered from severe government austerity, budget cuts, and conflicting agency leadership (D. Bray and M. Wexler 1996:222). And, in the end, the law had little impact on communities that were not already well organized for local forestry. This included almost all of the communities of the Sierra Chatina.

By the middle of his six-year term, Mexican President, Salinas de Gortari (1988-1994) began a series of neoliberal inspired reforms that ultimately took aim at Article 27 of the Mexican Constitution, the legal basis of land reform. ${ }^{3}$ In 1992, Article 27 was amended, ending the Mexican Government's 77 years of experimentation with communal land tenure. The revisions of Article 27 legalized the sale and leasing of communal or ejido lands. These changes, in effect, permitted the privatization of most communal and ejido lands. The law, however, does not provide for the sale or transfer of lease rights of forested lands-traditionally indivisible in the original 1917 law. Rather, communities that sell off their agricultural lands cede their forested lands to the state, which then become national property.

At the same time that Article 27 was being amended, major changes to forestry policy were heralded by the enactment of a new 1992 forestry law that replaced the 1986 act. The new law significantly deregulated the forestry sector-removing the complicated system of permits that had previously regulated the cutting, transportation, and processing of wood. Under the new law, all this paper work was replaced by a single stamp that is placed on cut logs when they are loaded for transport (D. Bray and M. Wexler 1996; C. Zabin

3. Article 27 of the Constitution of 1917 was the true linchpin of land redistribution in Mexico. President Salinas de Gortari's 1992 reforms gutted it eliminating much of the protection offered to Indian and peasant communities. 
1998). ${ }^{4}$ In a direct about-face from the 1986 act, the 1992 legislation encouraged longterm associations between logging firms and communities. Although several communities in the nearby coastal ranges of Guerrero have created long-term associations with the U.S. firm Boise-Cascade, none of the Chatino communities in Oaxaca have yet tested the provisions of the new laws, and much confusion still clouds issues related to their implementation (D. Bray and M. Wexler 1996; C. Zabin 1998).

The new law also eliminated the system of UCODEFOs, leaving communities to hire their own engineers to manage the process. Generally, this has meant that communities receive fairly poor technical services. For example, as recently as 1996, in the Chatino community of San Juan Lachao Viejo, community leaders contracting the technical services of a Oaxaca-based forestry firm scarcely consulted with their forestry technician who rarely traveled the 10 -hour drive into the mountains. Ultimately, poor oversight was the outcome; precautions for preserving soils and preventing fires were ignored, and the community was left with no post-harvest plan for reforestation. Although the technician and his firm were suggested by the Mexican Ministry of the Environment (SEMARNAP) as a government-certified option, the budget-strapped community chose them as the lowest bidder for services, and ultimately received what they paid for. In three other cases of communities surveyed in 1998, the commercial firms provided their own forestry technicians to the communities, with the results being an unfair assessment of timber values and poor oversight of pre- and post-harvest activities that would have been critical to sustainable practices.

When interviewed by Emanuel in 1998, Mexican government officials from the Ministry of Environment, SEMARNAP, were well aware of this situation. Yet the poorly funded, largely toothless agency is almost powerless to enforce regulations that ostensibly mandate equitable and sustainable forestry for both communities and commercial interests. Unless the agency sends representatives into the remote rural areas such as the Sierra Chatina where and when harvesting is taking place, SEMARNAP cannot oversee local harvest and post-harvest operations, and potential agency watchdogs are excluded once management plans are drafted and signed. The relationships among local political bosses, indigenous communities, and urban commercial firms have not changed much in the since the 1970s, but the Mexican federal government's lax oversight of the process has allowed collusive behaviors of these actors to continue under a new economic paradigm. This is symptomatic of the gradual 30-year evolution of the forest extraction process from a tight, often corrupted, government control to a neoliberal privatized system that allows private firms tremendously unregulated (or unenforced) latitude with rural communities and their forests.

As we have pointed out above, the most socially and environmentally tragic outcomes of this new regulatory paradigm shift are readily visible in native Chatino communities. It is usually the most marginalized communities in the Sierra Chatina-those characterized by high Spanish illiteracy and that are mostly monolingual Chatino- that are the primary victims of a system that seems to concentrate critical price and regulatory information in urban, ladino hands.

4. Although no doubts exist that the previous system of paper trails was a huge barrier to harvest and hence profits for the communities and companies involved, critics have argued that this has lead to easy replication of the hammers, and as a consequence, has encouraged timber theft. 
This leaves the communities without options for sound economically or ecologically sustainable forestry practices. As we outline below, there is a second dimension to the history of this tragedy 25 years in the making-the erosion of non-forest related livelihoods. The results of this erosion are that mestizo and indigenous communities are now forced to actively participate and compete in the commodification of their forests.

\section{Neoliberal Policy Effects on Livelihoods in the Sierra Cha- tina}

Aside from transformations of forestry policy, the even more deeply rooted changes affecting the exploitation of forests in the Sierra Chatina stem from the restructuring of the Mexican economy by global processes. These changes instituted through neoliberal reforms and policies have severely eroded local livelihood strategies, leaving communities to rely much more heavily on forests as a commodity and as replacement for lost incomes from other activities.

In the late 1980s and early 1990s, we have seen a significant shift in economic public policy objectives in rural Mexico, moving from social sector spending to private sector spending, accompanied by an aggressive pursuit of foreign exports in horticultural produce, basic grains, cotton, citrus, and beef (Sanderson 1992:434f). Article 17 reform added to a long list of policy 'reforms' that signaled both the end of state-sponsored agrarian reform and an encouragement for the peasantry to privatize their land tenure and "modernize" their production strategies towards more 'rational' alternatives. The latter implies the consolidation of lands to allow the creation of economies of scale effective enough to produce cash rather than subsistence crops (T. Barry 1995:16).

As part of these neoliberal policies, Mexican food policy also took a decidedly different turn during the early 1990s. Funding for the government subsidized food stores, CONASUPO, was withdrawn. Price subsidies were removed from basic food items such as corn tortillas, maize, commercial milk products and beans. State subsidies of production activities were also cut as a part of the efforts by the Salinas administration to privatize parastatals and other similar enterprises (T. Barry 1995:435). These changes in public food policies had direct consequences for small producers in the Sierra Sur. Instead of incentives to produce basic foods for the local, domestic economy, incentives are increasingly directed toward exports and specialized markets. Moreover, those small producers who continue to produce basic staples such as corn and beans increasingly must compete with cheaper farm products imported into the area, particularly from Mexico's largest trading partners, the United States and Canada. Among the primary effects of these changes is the greater articulation of Mexico's rural population in larger, international markets for subsistence.

In the Sierra Chatina, for more than a century, coffee has been the principle cash crop for both small- and large-scale producers, and the primary linkage between domestic and national or international markets. Local buyers in Santa Catarina Juquila and Santos Reyes Nopala-financed by buyer/exporters in Oaxaca, have traditionally monopolized the purchase of coffee by offers of credit against leans on their harvest. Typically, this type of credit takes the form of a combination of overpriced merchandise sold in their stores, and interest-bearing cash loans offered at usurious rates. As elsewhere in Mexico, small holders in the Sierra Chatina characterize their often-contradictory relationships with 
coffee buyers by referring to them somewhat derogatorily as coyotes (J. Greenberg 1981; L. Hernandez Diaz 1987; M. Nolasco 1972; W. Roseberry 1995).

The Mexican state, however, has repeatedly attempted to position itself as "the defender of the autonomy of the small coffee cultivator" (A.Beulink, 1979:218) by intervening in the marketing of coffee. In the 1940s, as world prices for coffee began to soar, the federal government instituted an aggressive public policy aimed at increasing Mexico's overall coffee exports. As part of these efforts, during the late 1940s the Mexican government created the Instituto Mexicano de Café (INMECAFE). INMECAFE was a typical institution of the Mexican corporate state, whose primary purpose was to act as an intermediary among large-scale producers, exporters, and merchants. When the administration of President Luís Echeverría (1970-1976) began its campaign of agrarian populism in the early 1970s, to break the relationship between debtor small producers and coffee merchants, the agency began by purchasing coffee directly from the campesinos. Although INMECAFE forced local coffee merchants and their agents to be more competitive, it was never able to deliver sufficient credit in a timely manner to break their power. Another attempt to increase coffee production was made through CONASUPO stores, which sold government-subsidized, cheap maize and beans to local producers hoping to encourage them to convert their subsistence lands to coffee production (R.González 1998:249).

When the administration of Carlos Salinas de Gortari (1988-1994) announced the restructuring and dismantling of INMECAFE in 1989, small holders in the Sierra Chatina were presented with the choice of either marketing their coffee though the local coyotes or participating in the small cooperatives organized by the National Indigenous Institute (INI), such as Kyaat Nu, Union of Indigenous Communities of the Isthmus Region (UCIRI), and Union of Indigenous Chatino Communities, among others. As was the case with INMECAFE, small cooperatives were unable to offer sufficient credit to small producers; so local coffee merchants continued to be the major source of credit for these growers.

When the International Coffee Organization (ICO), a global coffee cartel, announced in 1990 the failure of its member nations to renew an agreement on export limits, the world coffee market was inundated. Export coffee prices fell precipitously, and many local coffee merchants were ruined (see Figure 2). This situation, coupled with the effects of Mexican liberalization policy, led to the worst crisis in the coffee sector in almost 30 years (L. Hernandez Diaz and F. Célis Calleja 1994:217).

This bad situation became steadily worse as President Ernesto Zedillo continued his predecessor's policies of eliminating subsidies and favoring private sector investment (J. Adams 1997:162). Although there were some economic gains in the early 1990s, these were quickly lost in the sudden peso devaluations in December 1994 and January of 1995. These changes in currency values priced agricultural inputs beyond the reach of smallscale producers, forcing small holders once again into increasing dependency on local money lenders and coffee merchant coyotes who's loans were suddenly priced higher and bought far fewer necessities. While most small-scale coffee producers regularly used offfarm employment to shore up income gaps between harvests, the dire conditions of the Mexican economy of the mid-1990s forced many farm families to seek longer-term employment away from their homes. Small producers have since abandoned coffee production in some prime coffee producing municipios such as Santos Reyes Nopala, and are seeking other, more permanent means of garnering enough cash to augment their remaining subsistence production. 
FIGURE 2. Mexican Coffee Price per Pound, 1980 to 1993

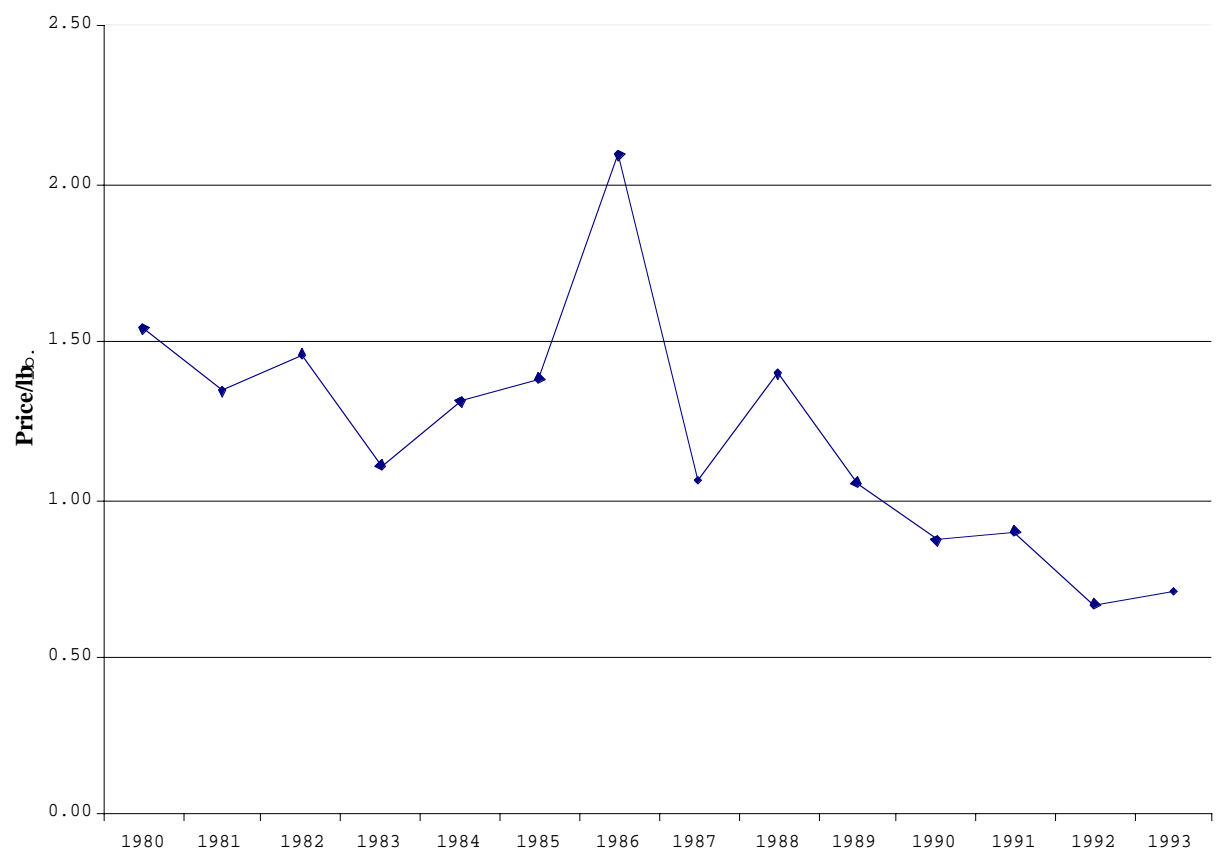

(Source: CEPAL 1996)

The reordering of the economic landscape in Juquila has resulted in the erosion of old peasant livelihood strategies and the creation of new ones. Eric R. Wolf (1966:3) has noted that peasants are inherently risk-averse. Under his logic, as old livelihoods become increasingly unfeasible, peasants should begin to look for less risky alternatives to replace coffee. And, if A.V. Chayanov (1986) is to be believed, peasants will work the minimum required to guarantee subsistence (plus a small surplus as insurance). Thus, one would expect Chatino peasants would replace untenable activities with ones of equal difficulty and gain. Neither prediction, however, appears to hold in the Sierra Chatina. Instead, it would appear that communities in the Sierra Chatina have become what Michael Kearney (1996) has characterized as "post-peasants." Neoliberal policies have over the last dozen years done what a century of cash cropping could not, that is, force the communities of the Sierra Sur into completely new economic logics. As a result, the old familiar boundaries of economic constraint and logic no longer apply in quite the same ways as they did in the Sierra as little as 25 years ago.

The Mexican economic crisis and neoliberal restructuring created new dependencies and new livelihood strategies that have had far reaching consequences for consumption and production decisions made by households. Behind these new livelihoods is a drive for cash, rather than simple subsistence. Unable to meet their needs with their own 
TABLE 1. Marginalization and Migratory Category of 13 municipios in the Sierra Chatina.

\begin{tabular}{|c|c|c|c|c|c|}
\hline Municipio & $\begin{array}{l}\text { Total } \\
\text { Population }\end{array}$ & $\begin{array}{l}\text { Percent } \\
\text { Indigenous }\end{array}$ & $\begin{array}{l}\text { Major } \\
\text { Language }\end{array}$ & $\begin{array}{l}\text { Grade of } \\
\text { Marginaliza } \\
\text { tion }\end{array}$ & $\begin{array}{l}\text { Migratory } \\
\text { Category }\end{array}$ \\
\hline $\begin{array}{l}\text { San Juan } \\
\text { Lachao* }\end{array}$ & 3,561 & 62.53 & Chatino & High & $\begin{array}{l}\text { Strong } \\
\text { Expulsion }\end{array}$ \\
\hline $\begin{array}{l}\text { San Juan } \\
\text { Quiahije* }\end{array}$ & 2,401 & 99.36 & Chatino & Very High & Expulsion \\
\hline $\begin{array}{l}\text { San Miguel } \\
\text { Panixtlahuaca* }\end{array}$ & 3,967 & 98.94 & Chatino & High & Attraction $\ddagger$ \\
\hline $\begin{array}{l}\text { San Pedro } \\
\text { Tutepec* }\end{array}$ & 35,376 & 57.71 & Chatino & High & Equilibrium \\
\hline $\begin{array}{l}\text { San Gabriel } \\
\text { Mixtepec** }\end{array}$ & 3,342 & 76.33 & Chatino & High & $\begin{array}{l}\text { Strong } \\
\text { Expulsion }\end{array}$ \\
\hline $\begin{array}{l}\text { Santa Catarina } \\
\text { Juquila* }\end{array}$ & 11,315 & 40.88 & Chatino & High & Attract ion\# \\
\hline $\begin{array}{l}\text { Santa Cruz } \\
\text { Zenzontepec* }{ }^{*}\end{array}$ & 11,576 & 81.47 & Chatino & Very High & $\begin{array}{c}\text { Strong } \\
\text { Attraction } \neq\end{array}$ \\
\hline $\begin{array}{l}\text { Santa Maria } \\
\text { Temaxcaltepec* }\end{array}$ & 1,495 & 95.62 & Chatino & Very High & $\begin{array}{l}\text { Strong } \\
\text { Expulsion }\end{array}$ \\
\hline $\begin{array}{l}\text { Santiago } \\
\text { Amoltepec }\end{array}$ & 7,540 & 91.08 & Mixteco & Very High & Attraction $\ddagger$ \\
\hline $\begin{array}{l}\text { Santiago } \\
\text { Yaitepec* }\end{array}$ & 2,346 & 99.55 & Chatino & Very High & $\begin{array}{c}\text { Strong } \\
\text { Attraction } \ddagger\end{array}$ \\
\hline $\begin{array}{l}\text { Santos Reyes } \\
\text { Nopala* }\end{array}$ & 11,582 & 83.90 & Chatino & Very High & Equilibrium \\
\hline $\begin{array}{l}\text { San Lorenzo } \\
\text { Texmelucan }\end{array}$ & 4,124 & 100.00 & Zapoteco & Very High & Equilibrium \\
\hline $\begin{array}{l}\text { Tataltepec de } \\
\text { Valdez* }\end{array}$ & 4,622 & 88.80 & Chatino & Very High & Expulsion \\
\hline
\end{tabular}

* Municipios with significant forested areas. Much of this area is biologically and commercially valuable pine-oak woodland.

$\$$ Attraction in these cases generally reflects semiannual migrations from neighboring municipios to harvest coffee during the peak of the season. Generally, large coffee plantations that account for the pull factor into these areas.

$=$ This municipio is not part of the District of Juquila but due to its significant Chatino population, it is included in all studies of the Sierra Chatina.(Source: INI n.d.)

production, households have been forced into strategies that bring needed cash, including yearly and semi permanent migration, intensification of cash cropping, and natural resource extraction. Most of these activities have been at the expensive of less 
remunerative subsistence crops. As a result, households increasingly have been forced to purchase their necessities in the market. Rather than following the traditional Chaynovian logic of production to fit the necessity of household reproduction, dependency on cash to acquire essential goods has caused households to become flow-through economies (J.Heyman 1990). This is unlike the peasant logic in which earnings are invested in production and consumption is minimized to a few essentials. In flow-through economies, cash-usually from wages - rather than being invested to increase household production and overall livelihood, moves quickly in and out of the household to meet its immediate needs. Under this logic, the need for cash-income becomes paramount, and even risky economic activities that produce cash will be favored over subsistence activities or other less remunerative endeavors. Thus, both Wolf's logic of risk-aversion, and Chaynovian difficulty-aversion fail to competently predict these post-peasant households behaviors.

\section{Migration}

In the past, when families needed extra cash, they tended to work on local coffee plantations, usually during the harvest. These migrations were generally within the region, and families would return to the same plantations year after year. As poor world prices have made coffee production increasingly unprofitable, and subsistence production has suffered with shifts in public policy, the economic marginalization of the Sierra Chatina (see Table 1), has driven many Chatino to seek employment in major tourist centers such as Acapulco, Hautulco, Oaxaca, and Puerto Escondido. Others have sought employment in Mexico City or the agricultural regions of Northwestern Mexico and the United States. Thus, the pace of cultural change in the region is dramatic, with migrants bringing home new ideas about the nature of capital, production, and culture. Many individuals no longer maintain their Catholic-Chatino religious belief systems that were ubiquitous less than 25 years ago. In recent years, workers, and often-entire families, have been drawn to busy tourist centers on the coast, as well as to the bustling market and tourist town of Santa Catarina Juquila to work in the construction trades. Equally common is semi permanent migration to Oaxaca City and Mexico City, strong attractions for men and women in the poor, Chatino towns of the District of Juquila.

Where 25 years ago, Chatino expressed deep fears about long distance-fears that should they die outside of the region their souls might not be able to find their way to the next world (J.Greenberg, 1981:103), men in most communities now express a keen interest in migrating to the United States. In many of these communities, men have made the long journey themselves. A few community members boasted that they had relatives living al otro lado (the other side of the international line). These are startling differences considering that until the late 1980s, Chatinos could not be found living outside of their home communities or home districts. By the early 1990s, Chatino-speaking municipios showed some of the highest migratory expulsion rates in the entire state of Oaxaca, and were comparable to other indigenous areas in the Sierra that have a long history of outmigration (See Figure 3). 
FIGURE 3. Migration in municipalities with 30 percent or more indigenous population in 1993.

OAXACA

MIGRACIÓN EN MUNICIPIOS CON 30\% Y MÁS DE POBLACIÓN INDÍGENA

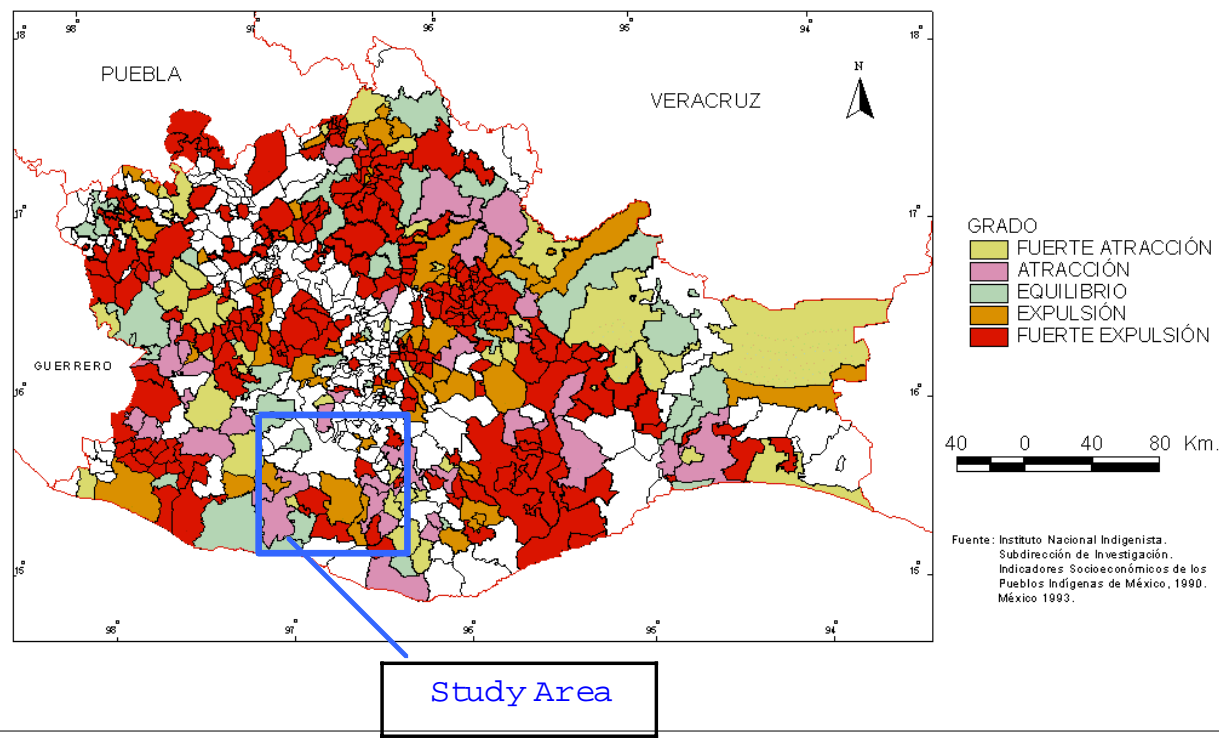

(Source: INEGI 1994)

Migration has some serious consequences for ecosystems in the Sierra Chatina. In the search for cash, families may diversify activities to the point where farm activities suffer. A labor scarcity is the first impact of migration. Scarce labor makes projects like maintaining fields and watersheds more difficult. Collins (1992:183) noted a similar situation in Peru where participation in day labor can imply an irreversible deterioration of the land through neglect. Secondly, absent Chatino adults cannot participate in local rituals of propitiation that affirm bonds between the land and the people. As the pool of participants in communities declines, the perceived importance of local cosmology declines as well. The children of migrants in some communities no longer share the same beliefs as their elders who may have stayed behind or may have a stronger history of participation in local rituals. This is particularly acute when migrant children are raised speaking Spanish as the lengua franca instead of Chatino. As Donald Worster has eloquently written: "thought grows in the interstices of habit" (1993:83). Hence, migrants return with new ideas about household economics, ecology, language, religion, and 
community that can be hazardous to the forests of the Sierra. Their influence is not only within their own generation, but also spreads through example to the next.

\section{The Coup de Grace: Hurricane Pauline and the Drought of 1998}

In the last 25 years, forest use has changed radically in the Sierra Chatina. These changes, as we have already noted, have resulted in a 40 percent loss of vegetative cover loss throughout the region. Commercial logging operations are responsible for much of this loss (Table 2) some of it, however, particularly near communities, is related to recent changes in the rural economy as communities harvest forests in their struggle to meet their needs for agricultural lands and wood for fuel. The sum of these activities has generated a pattern of forests that one Oaxaca-based biologist typified as "grossly fragmented beyond recovery." Mexico's economic restructuring has not only reshaped the economy of the Sierra Chatina, it has had profound consequence for its ecosystems.

TABLE 2. Commercial Timber Harvested in the District of Juquila from 1985$1998^{\text {a }}$

\begin{tabular}{clcc}
\hline Date & Municipio & Hectares & Cubic Meters \\
1985 & San Juan Quiahij & 800 & 38,814 \\
$1989-98$ & Santa Catarina & 827 & 60,181 \\
& Juquila & & \\
1989 & San Juan Quiahije & 179 & 11,849 \\
1990 & San Juan Quiahije * & & 11,867 \\
1991 & San Gabriel & N/A & 12,740 \\
& Mixtepec * & & \\
1991 & San Juan Quiahije & N/A & 19,452 \\
1992 & Santa Catarina & 51 & 17,488 \\
& Juquila & & 18,070 \\
1994 & San Juan Quiahije & 353 & 1,098 \\
1996 & San Juan Lachao & 14 & 181,559 \\
& Viejo & &
\end{tabular}

District Total

a. Unpublished data gathered from the Secretaria de Medio Ambiente, Recursos Naturales y Pesca, Subdirección de Oaxaca, Oaxaca de Juarez, June 1998.

(*Source: INEGI 1996)

These problems were further intensified by the devastating visits of Hurricanes Pauline and Rick in the fall of 1997, and by the nine-month-long drought that followed. When Pauline parked off of the coast of Oaxaca for nearly 7 hours, it generated winds in excess 
of 150 m.p.h. that wrecked most infrastructure in the region, caused countless deaths, and utterly destroyed both coffee and corn crops for 1998. Rick then entered the region a month later, it exacerbated the mudslides and downed more weakened trees on the southern slopes of the Sierra. In coffee producing areas, as much as 60 percent of the standing canopies were downed, crushing the coffee trees and leaving large sunny gaps in the forest that later burned the remaining plants. Many small coffee farmers expressed the futility of trying to clean up the mess. The hurricanes caused widespread damage to agricultural fields and towns in the watersheds of the Sierra, but even more importantly, Pauline's 150 m.p.h. winds blew down extensive tracts of secondary and primary forests (Figure 4).

FIGURE 4. Extensive timber blow down on the eastern flanks of Cerro de la Virgen, Juquila, Oaxaca July 1998.

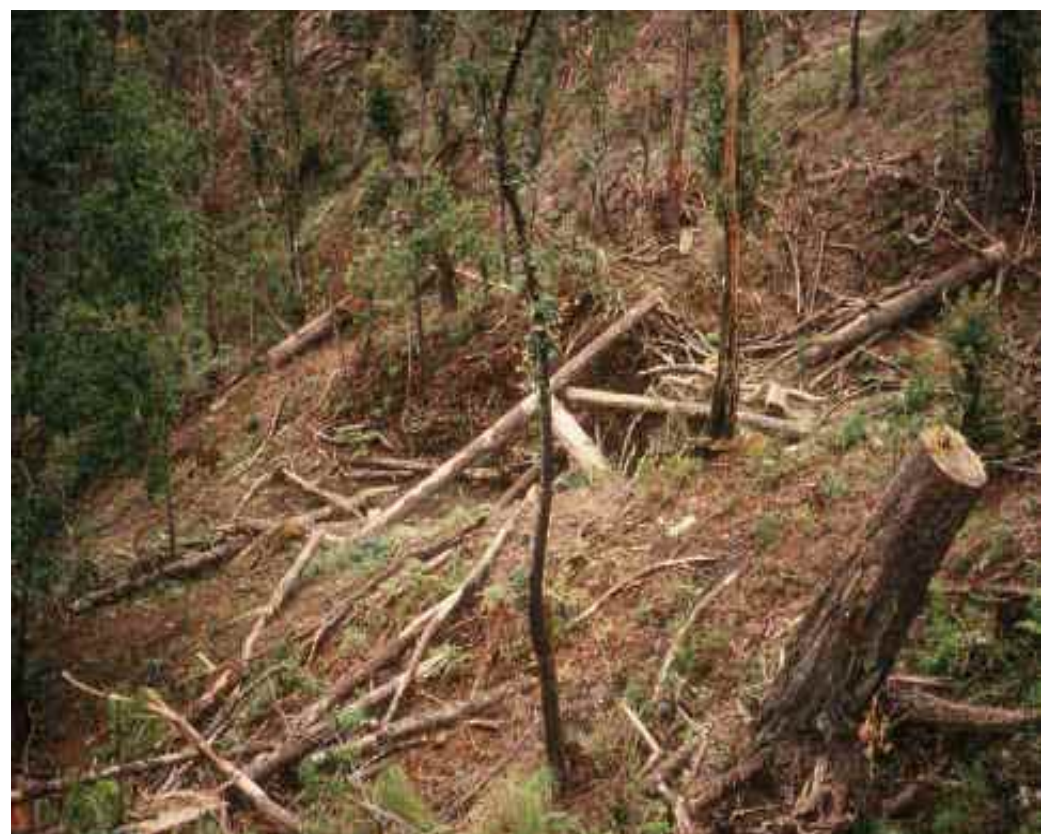

Photo by Robert M. Emanuel.

Throughout the entire region, communities without the resources to exploit such downed timber contracted commercial firms to harvest it, leading to a rush for access to the now-denuded lands. Wherever clandestine and illegal logging operations have been on the increase as roads and infrastructure have made it easier to extract the illegal timber from the area, the downed timber caused a "timber rush" as virulent as any gold rush. As the hurricane had almost completely devastated corn and coffee crops, leaving few alternatives in its wake, anyone who could afford a chain saw rushed to harvest what was left of the downed timber. The rush generated violent and bloody conflicts between individuals and communities over who had the rights to harvest particular lands and trees. 
In the vicinity of Santa Catarina Juquila, for example, an area known locally as Cerro de la Virgen became the site of violent conflict over the rights to harvest the downed timber. As Chatinos from neighboring Santiago Yaitepec immediately attempted to harvest the downed wood, Ladinos in Juquila contracted a comite de vigilencia to guard the valuable resource for their own use. Over a two-month period beginning in January of 1998, three people were shot, and at least one individual killed in the rush to harvest. The area's significance to both communities, and the subsequent fight to access the newly available resources resulted in the rekindling of an old conflict over the boundaries of the two. This conflict was extenuated by the fact that something of value could now be extracted from what was considered only marginally valuable lands 25 years ago (J.Greenberg 1981). The rush for the new natural resources in the economically struggling communities exacerbated already tense ethnic relations between mestizo and Chatino communities.

As the impacts of these El Niño events highlight, when these "natural" disasters struck, the rural economy was already extremely vulnerable after a decade of structural adjustments. As a result, the crisis generated was not only much greater than in previous similar events, but the repercussions were more prolonged, more profound, and more permanent. The long economic slide and climate-driven crisis have impacted local cash crop and subsistence production, and left small holders with few viable choices to generate livelihoods.

Smallholder Chatinos and mestizos appear to be abandoning coffee. Although these disasters might be a contributing factor-- we suspect that diminishing returns in an increasingly risky market are also responsible. For many growers, the hurricanes and drought were simply the last straw. Coffee buyers interviewed in 1998 expected to purchased less coffee this year than last-i.e. than after the hurricanes had devastated coffee plantings. As one coffee buyer explained, "prices are just too low and the quality of the cerezas (berries) is just too poor." In Santos Reyes Nopala, one of the best areas for low-elevation coffee production, many small coffee parcels have already been abandoned. Coffee parcels had not been cleared of downed trees or branches from the hurricanes, nor had plants been maintained (in some cases for years) indicating that parcels had become less lucrative long before the hurricanes struck. Even large plantation-style production in the district had been severely affected by both the extreme variability of the international coffee market and the vagaries of $\mathrm{El}$ Niño weather. Local administrators claimed poor production was the result of downed trees and branches, and extremely dry, hot conditions that persisted for nine months after the hurricanes. Administrators speculated that this would ultimately lead to a labor surplus, as they would be forced to turn away workers from the gates during the 1998 and 1999 picking seasons. They also noted that labor surpluses had been a fact of life since 1990. Because most coffee plantations also purchase local coffee production from small holders, their difficulties have also affected local merchants and small holders.

Corn production also was severely affected by the storms. Pauline and then Rick destroyed as much as 80-90 percent of the total corn crop in the fall of 1997. Mudslides removed entire fields just as they neared harvest. Even nine months after the hurricanes, in at least 20 sites surveyed in the District of Juquila, the severe soil erosion from the torrents of water that came down on deforested hillsides around the communities was still evident (see Figure 5). In some communities such as Santa Maria Amialtepec, San Juan Lachao Viejo, Santos Reyes Nopala, and Santa Catarina Juquila, fields were still unplanted by the time rains had again arrived in July of 1998. Their owners claimed it was not worth in 
replanting tierra muerta, or dead earth. As the widespread expulsion of migrants from the highland communities would seem to indicate, livelihood strategies are changing fast; and if traditional milpa-style subsistence agriculture is not dead, it is certainly in trouble.

\section{FIGURE 5. Evidence of extreme erosion caused by the torrential rains of Hurricanes Pauline and Rick, July 1998.}

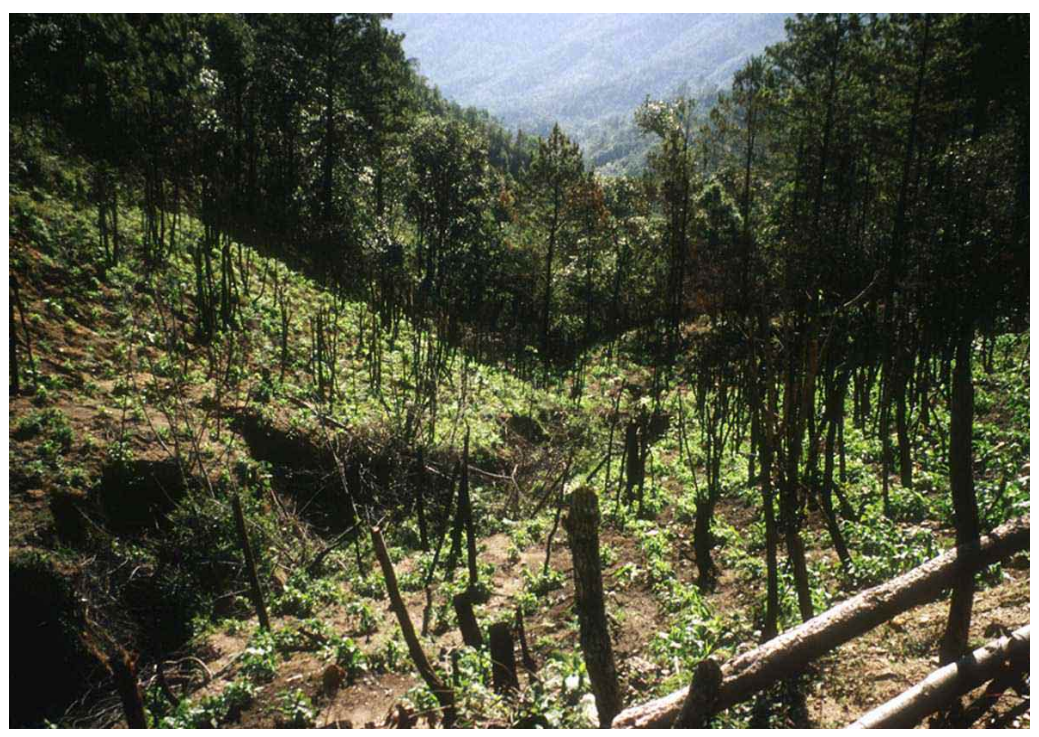

Photo taken by Robert M. Emanuel.

The most ecologically significant outcome of the hurricanes and drought was their effects on the forests of the Sierra Chatina. Like the destruction of coffee and subsistence agriculture, the effects of $E l$ Niño only served to intensify long-standing trends behind deforestation. As local livelihood strategies have become both increasingly unsure and cash-dependent, forests beckon as a ready source of cash. Unfortunately, as the infrastructure for extraction has improved, forests that once were largely only of local usevalue have become highly valued commodities. Although new policies cynically claim to return control over forests to communities, in fact, these policies, by making leasing and sales easier, have increased the pace with which forests are being alienated from communities. Where once peasants were free to cut wood for their own use, with their lands now leased, and cutting controlled by state agencies, they are defined as engaged in illegal forest extraction. The sad end to this story is that not only are forests disappearing at an alarming rate, but also the livelihoods of people who inhabit the region have been so eroded by the changing political economy and deteriorating ecosystem that there remain few local alternatives but out migration or engaging in illegal forms of production. 


\section{Conclusions: The Commodification of the Sierra Chatina}

The removal of the forest and corresponding damage to ecosystems of the Sierra are the products of three parallel processes. First, the Mexican state colluded with powerful timber interests to facilitate their extreme profit taking at the expense of healthy ecosystems. Second, the livelihoods of smallholders, such as subsistence corn producers and coffee growers, have been severely eroded by the Mexican state's neoliberal policies, leaving them with few economic options besides migration or illegal logging. Lastly, the 1997 and 1998 El Niño-driven storms and subsequent drought removed much of the remaining standing timber and the further exacerbated agricultural production in the region. Although these three processes were independent of each other, they worked together to weaken and destabilize the region's fragile human ecology.

The immediate economic impacts are evident in the abandonment of coffee and subsistence production as well as in out-migration by smallholders seeking income alternatives. At the same time there was the rush to harvest timber as an additional source of immediate income. The ecological consequences are plainly seen in severely eroded hillsides and fields, the removal of all saleable biomass from once-forested areas, and the altering of watercourses. The social impacts are also clearly seen in the increased tensions between different ethnic and social groups contending for control of the now-valuable timber, the out-migration of community members and accompanying dilution of indigenous culture, social identity, and economic autonomy.

These processes can not be viewed easily and understood just from a local perspective, but also must be contextualized within a greater political ecology in which the Mexican government has effectively divided the trees from the forest, the forest from the watersheds, and the land from the people who use it. Agricultural, economic, and natural resources policy all contribute directly to what we will call here, a political ecology of commodification.

The Mexican government's natural resources policy has created a hierarchical arrangement of agencies and institutions in place to deal with different aspects of the landscape and its management. While this policy of divide and rule may be sound statecraft, it does not facilitate sound care for ecosystems (J.Greenberg 1998:135). These agencies compete for control over natural resources, budgets, and political favors. Soils, water, forests and even forest fire control are separated by agency lines. Effectively, this means that each agency manages only within its specific mandate and only in terms of its own political interests. This becomes the fertile ground for collusion between disparate agencies and commercial interests.

The division of the forest from the land, and land from people has facilitated the easy conversion of each of these ecological elements into commodities that are then managed in an even larger institution-the global capitalist market (J.O'Connor 1998:83). Ecological values are hence managed from afar-removed from their local context and control by local people with a more intimate knowledge of them. More importantly, the global market for forest products places values on specific elements of the local ecosystem, and not on the forest itself. The cutting of trees then becomes rationalized by the economic logic of capitalist wood markets, and other values such as the ecological or cosmological significance of the entire forest become secondary.

Mexican forestry and agricultural policies are the outcome of nonlocal economic and political processes that are so foreign and so distant from the resources themselves that they often shut out the most important potential contributions of local communities. Local 
values and knowledge are neglected in the face of larger, more distant actors who compete over the rights to the forest commodities. Nor are these actors adept at coordinating their efforts to manage particular resources, divided as they are by different motivations and disparate foci. For example, the Mexican government passed legislation in 1986 and 1992 that divided environmental and forest management between two competing agencies: the federal environmental ministry and the ministry of forests. Hence, for both commercial firms and communities interested in forestry, the path through federal regulations and bureaucracies is unclear (World Bank 1995:xii). Because they are not local, these new actors can ignore the consequences of their policies for far longer than local communities. To top it all off, it is the local community that has long been left out of the process of management, and is instead often assigned the obligations and duties of managing resources but not necessarily the rights to them. This has been amply illustrated by examples from the Sierra. On such example described in this paper is San Juan Lachao, which leased timber harvesting rights to a Oaxaca-based commercial logging firm, but was left with the responsibility for the post-harvest clean up and reforestation, something for which this highly marginalized community was not prepared.

In summary, we wish to observe that the destruction of the Sierra Chatina is two-fold. We have demonstrated that the destruction of the region's fragile watersheds by both climatic and human agency has generated a profound economic and social violence for the communities within them. Both Chatino and mestizo communities have been forced into new economic logics with changes in regional and macroeconomic policy. More importantly, however, these logics have resulted in the deterioration of community solidarity and cohesiveness. These kinds of changes, combined with the sudden availability of newly commodified resources led to the exacerbation of ethnic tensions between communities and within them. This case study of political ecology in the Sierra Chatina illustrates the important linkages between economic policy, community structure, ethnicity, and human ecology that are often overlooked when both people and their landscapes are forced into the global marketplace as homogeneous commodities.

\section{References}

Adams Jr., John A.

1997 Mexican Banking and Investment in Transition. Westport, CT: Quorum Books.

Barry, Tom

1995 Zapata's Revenge: Free Trade and the Farm Crisis in Mexico. Boston: South End Press.

Beulink, Anne Marie

1979 "Quitame un retrato: una ethnografía de la region Mixe, Oaxaca." Unpublished Manuscript.

Bray, David Barton and Matthew B. Wexler

1996 "Forest Policies in Mexico." In Changing Structure of Mexico: Political, Social and Economic Prospects. Laura Randall, editor. New York: M.E. Sharpe.

Chayanov, A.V.

1986 The Theory of Peasant Economy. D. Thorner, B. Kerblay, and R.E.F. Smith, editors. Madison: University of Wisconsin Press.

Collins, Jane 
1992 "Marxism Confronts the Environment: Labor, Ecology, and Environmental Change." In: Understanding Economic Process. Sutti Ortiz, editor. Lanham: University Press of America.

González R., Alvaro and Nemesio J. Rodríguez

1995 "Etnias y recursos forestales en México.” Cuadernos de Sur. Año 3, septiembre 1995, Oaxaca, Mexico.

González, Roberto J.

1998 "The Political Economy of Coffee in the Sierra Juarez of Oaxaca, Mexico.” In: Research in Economic Anthropology Volume 19, pp. 239-266.

Goodman, David, and Michael Redclift, editors.

1991 Environment and Development in Latin America: The Politics of Sustainability. Manchester: Manchester University Press.

Greenberg, James B.

1998 The Tradegy of Commodization: The Political Ecology of the Colorado River Delta's Destruction. Research in Economic Anthropology, Vol.19, pp. 133-149.

1989 Blood Ties: Life and Violence in Rural Mexico. Tucson: University of Arizona Press.

1981 Santiago's Sword: Chatino Peasant Religion and Economics. Berkeley: University of California Press.

n.d. "Territorialization, Globalization, and Dependent Capitalism in the Political Ecology of the Upper Gulf of California.” Unpublished manuscript.

Hernández Díaz, Luís, and Fernando Célis Callejas

1994 "Solidarity and the New Campesino Movements: The Case of Coffee Production." In: Transforming State-Society Relations in Mexico: The National Solidarity Strategy. Wayne Cornelius, Ann L. Craig, and Jonathan Fox, editors. San Diego: University of California at San Diego, Center for U.S.-Mexican Studies.

Heyman, Josiah

1990 "The Emergence of the Waged Life Course on the United States-Mexican Border." American Ethnologist. 17(2): 349-59.

Instituto Nacional de Estadistica Geográfica e Informatíca/Instituto Nacional Indigenista. Subdirección de Investigación

1994 Indicadores Soioeconómicas de los Pueblos Indígenas de México, 1990. Sistema de Información Geográfica. México.

Instituto Nacional de Estadistica Geografia e Informatica

1996 Anuario estadistico del estado de Oaxaca, Edición 1996. Aguascalientes: INEGI.

Instituto Nacional Indigenista (INI), Distrito Santa Catarina Juquila

n.d. Unpublished data on file at the Santa Catarina Juquila office. Recorded by author on July 8, 1998.

Kearney, Michael

1996 Reconceptualizing the Peasantry: Anthropology in Global Perspective. Boulder, CO: Westview Press.

Liverman, Diana and Patterson, Mark. n.d. Unpublished Change Detection Analysis of the Sierra Sur, Oaxaca, Mexico.

Nahmad Sitton, Salomon, Álvaro González, Marco A. Vásquez 1994 Medio Ambiente y Tecnologías Indígenas en el Sur de Oaxaca. Centro de Ecología y Desarrollo: Oaxaca. 
Nahmad Sitton, Salomon, Álvaro González, Nemesio J. Rodriguez, Juan Martinez, Filemon Perez, y Rene Molina

1993 Informe del Estudio: Participación Social de los Pueblos Indigenas y Campesinos en el Manejo y Conservación del Recurso Forestal para el Banco Mundial y el Gobierno de Mexico. Oaxaca.

Nolasco Armas, Margarita 1972 Café y Sociedad en México. México D.F.: Centro de Ecodesarrollo.

O'Connor, James 1998 Natural Causes: Essays in Ecological Marxism. New York: Guilford Press. Roseberry, William

1995 "Introduction" In Coffee, Society and Power in Latin America. William Roseberry, Lowel Gudmundson and Mario Samper Kutschbach (eds.) Baltimore: Johns Hopkins University Press, Pages 1-37.

Sanderson, Steven

1992 "Mexican Public Sector Policy Under Agricultural Trade Liberalization." Policy Studies Journal. 20(3): 434-435.

UN Comisión Economica para America Latina y el Caribe (CEPAL)

1996 Información Basica del Sector Agropecurario, Subregión Norte de America Latina y el Caribe, 1980-1994. Mexico: ECLA

Weaver, Thomas

1996 "Mapping the Policy Terrain: Political Economy, Policy Environment, and Forestry Production in Northern Mexico." Journal of Political Ecology. Vol 3: 37-68.

Wolf, Eric R.

1966 Peasants. Englewood Cliffs, NJ: Prentice Hall.

\section{World Bank}

1995 Mexico Resource Conservation and Forest Sector Review.

Worster, Donald

1993 The Wealth of Nature: Environmental History and the Ecological Imagination.

Oxford: Oxford University Press.

Zabin, Carol

1998 "Free Markets and Forests: Community-Based Forestry in the Era of Neoliberal Reform." In: The Transformation of Rural Mexico: Reforming the Ejido Sector. Wayne A. Cornelius and David Myhre, editors. Center for U.S.-Mexican Studies: University of California, San Diego.

1993 "El mercado de la Madeira en Oaxaca." Cuadernos de Trabajo Empresas y Ecodesarrollo No. 1. México, D.F.: Inter-American Foundation/Saldebras.

\section{Abstracts}

This paper outlines the major factors contributing to deforestation in the Sierra Chatina of Oaxaca, Mexico and examines the role played by neo-liberal restructuring in these processes. The last 25 years of rural development in the Sierra Chatino has been accompanied by increasingly large-scale environmental changes. The most obvious outcome has been the loss of 40 percent of the areas natural vegetation. Deforestation has accelerated and exacerbated flooding and climate changes in the region as witnessed by the effects of El Niño driven storms such as Hurricane Pauline. This paper will focus on these processes of deforestation in the region. In this paper, we argue that the Mexican 
government's neo-liberal policies have encouraged the commoditization of the Sierra Chatina forests at the expense of long-term ecological sustainability. Since 1992, Mexico has moved toward privatization of forests by removing the legal roadblocks to leasing of ejido and communal lands. Moreover, as neo-liberal policies have devalued the currency, eliminated subsidies, the Chatino have been pushed deeper into poverty, and into unsustainable uses of their forests. Thus, we contend that transformations of land-use patterns seen in these coastal mountains are part of a fundamental shift in local livelihoods from subsistence to cash-based strategies.

Keywords: deforestation, Mexico, Oaxaca, Chatino, neo-liberal policy, ecological sustainablity, migration, political ecology, el Niño, privatization, climate change, environmental degradation, rural development.

\section{Resumen}

Este papel traza los factores principales que contribuyen a la deforestación en la Sierra Chatina de Oaxaca, México y examina el papel desempeñado por la restructuración neoliberal en estos procesos. Los últimos 25 años del desarrollo rural en la sierra Chatino han sido acompañados por los cambios tremendas ambientales. El resultado más obvio ha sido la pérdida del 40 por ciento de la vegetación natural de la área. La deforestación ha acelerado las inudaciones y cambios del clima exacerbados en la región como es atestiguado por los efectos de las tormentas conducidas por el Niño, tales como el huracán Pauline. Este papel enforcará en estos procesos de la deforestación en la región. En este papel, discutimos que las políticas neo-liberales del gobierno Mexicano han alientado el comoditización de las bosques de la sierra Chatina a costa de la sosteniblidad ecológica a largo plazo. Desde 1992, México ha optado por la privatización de bosques y lo ha logrado quitando los obstaculos legales para alquilar con los ejidos y las tierras comunales. Por otra parte, a consequencia de las políticas neo-liberales que han devaluado la moneda y eliminado los subsidios, los Chatinos han sido empujados más a la pobreza, y forzados a hacer usos insostenibles de sus bosques. Así afirmamos que las transformaciones de los modelos de uso de tierras considerados en estas montañas costeras son parte de una cambio fundamental en sustentos locales de la subsistencia a las estrategias monetarias.

Palabras Claves: deforestación, México, Chatino, políticas neo-liberales, sosteniblidad ecológico, migración, ecológica política, el Niño, privatización, cambios de clima, degradación ecológica, desarrollo rural.

\section{Résumé}

Cet article expose les facteurs majeurs qui contribuent à la déforestation dans la Sierra Chatina, Oaxaca, Mexique et examine le rôle de la restructuration néo-libérale dans ces processus. Les vingt cinq années dernières de développement rural dans la Sierra Chatina ont été accompagnées par des changements environnementaux continus et d'une grande importance. Le résultat le plus évident est la perte de $40 \%$ de la végétation naturelle de la région. La déforestation a été accélérée et a exaspéré les inondations et les changements climatiques dans la région comme démontrent les effets d'El Nino et les tempêtes qu'il a causé tel que la tempête Pauline. Cet article examine les processus de déforestation dans la région. Dans cet article on argumente que les politiques néo-libérales du gouvernement mexicain ont encouragé la commercialisation des forêts de Sierra Chatina au dépit d'une 
écologie durable à longue terme. Depuis 1992, le Mexique s'est orienté vers la privatisation des forêts par l'abolition d'obstacles légaux qui contrôlaient les crédits-bails d'ejido et des terres communales. En outre, comme les politiques néo-libérales ont dévalué la monnaie, élimine les subventions de l'état, les Chatinos ont été encore plus appauvrit et ont été poussé à des usages non-durables de leur forêts. Donc, on peut conclure que les transformations de l'usage des terres qu'on a observé dans les montagnes du littoral font parti d'un changement fondamental dans les moyens d'existence locaux qui consiste en un mouvement d'une stratégie de subsistance à d'autres basées sur des activités génératrices de revenues.

Mots Clés: déforestation, Mexique, Oaxaca, Chatino, politique néo-libérale, écologie durable, emigration, écologie politique, El Niño, Privatisation, Changement climatique, Degradation environnementale, developpement rural. 
Lluvia Enojada-Tyoo Kuasi': The Political Ecology of Forest Extraction

This page intentionally left blank 